\title{
最近のオゾン漂白技術とオゾン／酸素の工業的利用について
}

\author{
テイサン株式会社播磨テクニカルセンター営業企画・開発事業部 英 和 男
}

\section{Currently Ozone Bleaching Technique and Industrial Usage of Ozone/Oxygen Gas}

\section{Kazuo Hanabusa}

Business Management \& Development Division, Teisan Co., Ltd.

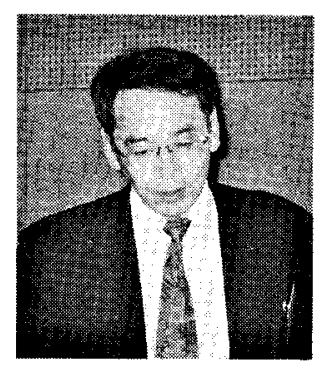

Recently, ozone based bleaching technique is not only available for TCF, but also for ECF bleaching sequence included (DZ) or (ZD) stage to obtain more strong pulp property.

It should be selected optimal ozone/oxygen supply system for each mill's condition by economical reason. "Over The Fence" solution enables the customer to have the benefit of the most appropriate ozone/oxygen supply option without detracting capital and human resources from the mill's core business.

For the safety to handle ozone/oxygen gas in the industrial mill, we confirmed the technical aspects through our laboratory test.

\section{1. オソン漂白実施工場}

世界の主要なパルプ工場では，工場廃水の改善及び 漂泊コスト削減を目的として, 酸素脱りグニン法が採 用されている。酸素脱リグニン用の酸素がス供給方法 として, 今日各パルプ工場においては, オンサイト酸 素ガス発生設備の設置が進んできている。そのために パルプ工場に扔ける，オゾン漂泊の採用は非常になや すくなってきているのが現状である。1992 年に世界 で最初のオゾン漂白が工業的規模でスタートアップし て以来, 急速な普及がみられ，表 1 で示したように 1996 年 4 月現在で 18 所の工場で運転もしくは，操 業のための建設が進められている1”。当初, オゾン漂 白技術は，AOX 規制ならびにヨーロッパを中心とし たパルプ市場の要求による TCF パルプ需要により, TCF 漂白シーケンスに取り入れられてきた。しかし 現在では, オゾン漂白は ECF シーケンスの漂白段と して, 環境問題の改善のみだけでなく，漂白コストの
削減を目的として採用が准んでいる。

OZED, OZ(EOP)DD というようなオゾン漂白を ベースにしたECFシーケンスが漂白コストの面でも 非常に優れているという報告がすでにある2。

酸素, オゾン, 二酸化塩素という ECF, TCF 用漂 白薬品の漂白シーケンス中での組み合わせは, 収率, 品質及び漂白コストの面で多くの研究がなされている。 この中でそれぞれの漂白薬品の特徴を十分に生かした 漂白シーケンスが二酸化塩素 (ZD) もしくは (DZ) 漂白段であり，単段で両者の反応が行われるシーケン スである。

オゾン漂白をベースにした ECF- (DZ) 漂白パルプ の強度は, ECF-D $100 \%$ 漂白パルプと同等であり, 漂白 薬品コストは著しく低減できる。Sappi Ngodwana ${ }^{3)}$, Kymmene-Pietarsaarri $^{4)}$, Stora Billerud ${ }^{5)}$ 工場では, (ZD) シーケンスが採用されており，Votorantim 社 の Celpav 工場で (DZ) シーケンスでの漂白ライン が建設中と報告されている゙ 。 


英和男

表 1 オゾン漂白採工場一覧 ${ }^{11}$

オゾン漂白プラント工場（1996 年 4 月現在）

\begin{tabular}{|c|c|c|c|c|}
\hline 会 社 名 & 工 場 & $\begin{array}{l}\text { オゾン } \\
\text { 発生量 } \\
(\mathrm{kg} / \mathrm{h})\end{array}$ & 稼動 & 品 \\
\hline LENZING & LENZING, Austria & $40^{*}$ & 1992 & TCF SULFITE (DISS) \\
\hline UNION CAMP & FRANKLIN, Va., USA & 280 & 1992 & ECF KRAFT \\
\hline SÖDRA CELL & MÖNSTERAS, Sweden & 210 & 1992 & TCF KRAFT \\
\hline STORA BILLERUD & SKOGHALL, Sweden & $40^{*}$ & 1992 & $\mathrm{ECF} / \mathrm{TCF}$ KRAFT \\
\hline MODO PAPER & HUSUM, Sweden & $200^{*}$ & 1993 & $\mathrm{ECF} / \mathrm{TCF}$ KRAFT \\
\hline KYMMENE & PIERTARSAARI, Finland & $100 / 100^{*}$ & $93 / 94$ & $\mathrm{ECF} / \mathrm{TCF}$ KRAFT \\
\hline METSÄ-BOTNIA & KASKINEN, Finland & $300^{*}$ & 1993 & $\mathrm{ECF} / \mathrm{TCF}$ KRAFT \\
\hline PETERSON & SÄFFLE, Sweden & $30^{*}$ & 1994 & TCF SULFITE \\
\hline SCA & OSTRAND, Sweden & $>>100^{*}$ & 1995 & TCF KRAFT \\
\hline SAPPI & NGODWANA, South Africa & $270^{*}$ & 1995 & ECF KRAFT \\
\hline PONDEROSA & MEMPHIS, Tenn., USA & $70^{*}$ & 1995 & RECYCLEDMKT PULP \\
\hline BACEL & CAMACARAI, Brazil & $60^{*}$ & 1996 & TCF PH KRAFT \\
\hline METSÄ-RAUMA & RAUMA, Finland & $420^{*}$ & 1996 & TCF KRAFT \\
\hline CONSOLIDATED & WISC. RAPIDS, Wi., USA & & 1996 & ECF KRAFT \\
\hline VOTORANTIM/CELPAV & LUIS ANTONIO, Brazil & $180^{*}$ & 1996 & ECF KRAFT \\
\hline VOTORANTIM/SIMAO & JACAREI, Brazil & $180^{*}$ & 1997 & $\mathrm{ECF} / \mathrm{TCF}$ KRAFT \\
\hline KLABIN & MONTE ALEGRE, Brazil & & 1997 & TCF KRAFT \\
\hline
\end{tabular}

稼動中／建設中合計：18 工場

（*）印は，オゾン濃度 $10 \mathrm{wt} \%$ 以_t:で処理

\section{2. オゾン漂白技術}

\section{$2.1 （ \mathbf{D Z})$ もしくは（ZD） シーケンスの反応}

Lachenal, Chirat 等の研究でば7),8)，オゾンの選択 的脱リグニンについて，図 1 に示されている。例えば 中間の洗浄を伴わない (DZ)，(ZD) 段は，Z及び D 単独よりも Kappa NO. 低下が大きくはるかに高い 漂白処理が出来る。これは, オゾンと二酸化塩素のそ れぞれ異なった選択性が相乗的に作用するものと理解 できる。最近の Xu, et. $\mathrm{a} 1^{9)}$.の研究によると, ある 種のアルコールと有機酸の存在によりオゾンの選択的 反応性が得られると示されている。

\section{2 (DZ) 段の最適化}

Liebergott, Lachenal, Chirat の研究結果の 1 例 を表 2 に示した。

$\mathrm{D}_{100 \%} \mathrm{ECF}$ 及び (ZD) シーケンスでオゾン添加 $\mathrm{kg}$ に対して二酸化塩素の置換出来る $\mathrm{kg}$ を置換率として あらわした。

単段でのオゾン，二酸化塩素の適用は，オゾンと二 酸化塩素の化学量論的酸化力での置換率よりも大きく なる。Lachenalによれば, 二酸化塩素のオゾンへの

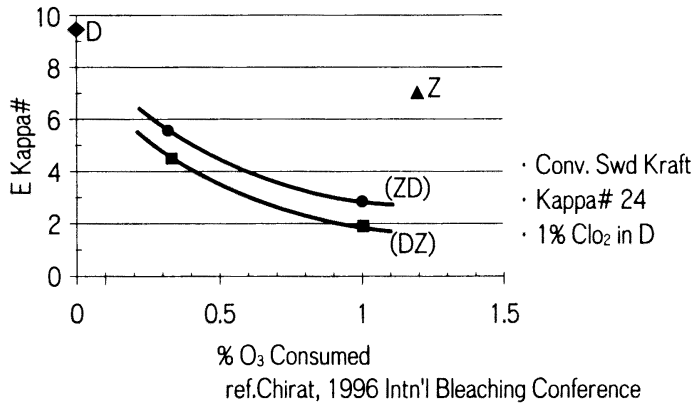

図 1 D , (ZD), (DZ), Z 齐シーケンスの脱リグニ ン効率比較

置換率は, ソフトウッドで $2.5 \sim 3.0 \mathrm{kgClO} / \mathrm{kgO}_{3}$, ハードウッドで 2.2〜 $4.0 \mathrm{kgClO}_{2} / \mathrm{kgO}_{3}$ となっている。 また，(DZ）段でオゾンを添加する際の酸前処理は, Lachenalによれば必要がないとされている。通常の $Z$ 段の前に添加される硫酸 $10 \mathrm{~kg} / \mathrm{PT}$ が節減されるこ とになる。

\section{$2.3 （ \mathrm{DZ})$ 段漂白でのパルプ強度}

Dillner と Tibblingによって報告されている (DZ) 漂日パルプの機械的強度について $\mathrm{O}(\mathrm{DC})(\mathrm{EO}) \mathrm{D}$ 
表 2 テスト結果の一例 HARDWOOD

\begin{tabular}{lcccc}
\hline \multicolumn{1}{c}{ 漂 I'1 } & $\begin{array}{c}\mathrm{D}_{0} \\
\text { シーケンス }\end{array}$ & $\begin{array}{c}\left(\mathrm{D}_{0} Z\right) \\
\mathrm{Ep} \mathrm{D}_{1}\end{array}$ & $\begin{array}{c}\mathrm{D}_{0} Z \\
\mathrm{Ep} \mathrm{D}_{1}\end{array}$ & $\begin{array}{c}\mathrm{Ep} \mathrm{D}_{1} \\
\mathrm{Ep} \mathrm{D} \mathrm{D}_{1}\end{array}$ \\
\hline $\mathrm{O}_{3} \%$ Charge & $\mathrm{n} / \mathrm{a}$ & 0.6 & 0.6 & 0.6 \\
$\mathrm{O}_{3} \%$ used & & 0.41 & 0.36 & 0.56 \\
$\mathrm{ClO}_{2} \%$ Charge & 2.62 & 1.55 & 1.55 & 1.35 \\
$\mathrm{ClO}_{2} \%$ used & 2.55 & 1.50 & 1.50 & 1.44 \\
占色度\% ISO & 87.8 & 89.0 & 89.9 & 87.9 \\
粘度 mPa.s & 21.7 & 19.6 & 18.9 & 18.5 \\
転換率 & $\mathrm{n} / \mathrm{a}$ & $>2.6$ & $>2.9$ & 2.0 \\
$\mathrm{AOX} \mathrm{kg} / \mathrm{t}$ & 0.8 & 0.32 & 0.35 & 0.20 \\
\hline
\end{tabular}

Hwd pulp Kappa 15, 33.0 mPa, Do 3.5\%, $\mathrm{Z}_{\mathrm{LC}}$

(ED) と O (DZ) (EOP)D (ED) シーケンスの比較を 表 3 にまとめな ${ }^{10)}$ 。KappaNO 13.5 の酸素脱りグ二 ンパルプを用い, オゾン添加率 $5.6 \mathrm{~kg} / \mathrm{PT}$ の場合と $\mathrm{D}_{50 \%} / \mathrm{C}_{50 \%}$ の埸合と比較した結果, 引き裂き, 破裂, 引張とも间じ強度が得られている。

\section{4 (DZ) 段の設備}

（DZ）段は，(EO）段設備と问様のパルプ処理装置 でオゾン漂白が行える。もし, 中濃度塩素漂白段が既 存設備として稼動されている場合には, 既存の二酸化 塩素添加ミキサーの前もしくは後ろにオゾン添加用の ミキサーを設置するのみで（DZ）設備が完成する。 このような場合, 二酸化塩素漂白塔は, オゾン添加後 のガスとパルプのセパレーターとして利用される。ス クラバーより四収されるオゾン反応後の酸素ガスは,
(EO), 酸素脱リグニン, ポリサルファイド液の生成, 石灰キルンの酸素富化, 白液の酸化, 活性污泥処理槽 の酸素曝気等に利用できる。また，オゾン発生用の酸 素ガスは，オンサイト酸素ガス発生装置によって供給 されるのがコスト面で有利となるであろう。パルプ工 場での経済的な酸素ガス利用については後段でも述べ る。

Lachenal, Dillnerによれば, 二酸化塩素とオゾン の注入の間の時間は, 30 秒〜2 分が最適の結果となる と言われている。また最近では, Chirat, Lachenal ${ }^{8)}$ は, 二酸化塩素とオゾンの反応時間は, 5 分間以上を保持 してもKappaの低下はもはや見られないという研究 結果がある。一方, 二酸化塩素の消費に要する反応時 間は，60～70\%の二酸化塩素を置き換えた場合，1 分 間以内で消費されるとPyke ${ }^{11)}$ により発表されている。

一般的な (DZ) 段で添加されるオゾンは, $4 \mathrm{~kg} /$ PTであるので，1台のミキサーで十分に反応を行う ことが出来る。工場規模の操業例では, オゾン圧力 10 パール, オゾン濃度 $12 \mathrm{wt} \%$ の条件でオゾンガスは $95 \%$ の消費が達成される。

\section{3. 工場規模での（DZ）もしくは（ZD）の 試み}

表 4 の各工場では，すべて中濃度でパルプが処理さ れており, オゾン $1 \mathrm{~kg}$ 添加に対してほぼ $3 \mathrm{~kg}$ の二酸 化塩素が置き換えられている。

また，オゾン漂白をべースとした ECF 漂白シーケ ンスでは, 旧来の漂白シーケンスと比較して, 環境問 題の解決と同時に漂白コストの節減が可能となる。表 5 にUnion Camp $\mathrm{Co}^{12)}$, と Stora ${ }^{5)}$ で発表されてい

表 $3(\mathrm{DZ})$ 漂白パルプの強度分析 ${ }^{10)}$

\begin{tabular}{l|c|c}
\hline \multicolumn{1}{c|}{ ソフトゥッド } & $\begin{array}{c}\text { 参照シーケンス } \\
\text { OD 50 (EO) } \mathrm{D}(\mathrm{ED})\end{array}$ & $\begin{array}{c}\text { (DZ)ECF シーケンス } \\
\text { O(DZ) (EOP) D (ED) }\end{array}$ \\
\hline $\mathrm{O}_{3}$ Charge $(\mathrm{kg} / \mathrm{pt})$ & 0 & 5.6 \\
\hline Brightness $(\% \mathrm{ISO})$ & 90.1 & 90.0 \\
\hline Viscosity $\left(\mathrm{dm}^{3} / \mathrm{kg}\right)$ & 934 & 787 \\
\hline Revolution $(\mathrm{PFI})$ & 1,000 & 1,000 \\
\hline Slowness $(\mathrm{SR})$ & 16.5 & 17.0 \\
\hline Tensile Index $(\mathrm{kN} / \mathrm{kg})$ & 80 & 80 \\
\hline Burst Factor $(\mathrm{MN} / \mathrm{kg})$ & 5.7 & 5.5 \\
\hline Tearlndex $\left(\mathrm{Nm}^{2} / \mathrm{kg}\right)$ & 17.0 & 16.5 \\
\hline Density $\left(\mathrm{kg} / \mathrm{m}^{3}\right)$ & 660 & 650 \\
\hline
\end{tabular}


表 4 （DZ）（ZD）漂白の工場規模での結果

\begin{tabular}{|c|c|c|c|c|c|c|c|c|}
\hline \multicolumn{3}{|c|}{ (DZ), (ZD) Mill Scale } & & & Previous & Now & & \\
\hline \multirow{2}{*}{ Mill } & \multirow{2}{*}{ Location } & \multirow{2}{*}{ Sequence } & Pulp & $\mathrm{O}_{2}$ & $\mathrm{ClO}_{2}$ & $\mathrm{ClO}_{2}$ & Ozone & $\begin{array}{l}\text { Replacem } \\
\text { ent } \\
\text { ratio }\end{array}$ \\
\hline & & & Type & Kappa & $\begin{array}{c}\mathrm{kg} / \\
\text { ODMT }\end{array}$ & $\begin{array}{c}\mathrm{kg} / \\
\text { ODMT }\end{array}$ & $\begin{array}{c}\mathrm{kg} / \\
\text { ODMT }\end{array}$ & $\begin{array}{c}\mathrm{kgClO}_{2} / \\
\mathrm{kgO}_{3}\end{array}$ \\
\hline Stora & Bilerud & $\mathrm{OA}(\mathrm{ZD})(\mathrm{EOOP}) \mathrm{DED}$ & SW & 13 & & & $2 \sim 4$ & 1.5 \\
\hline Kymmene & Pietasaari & $\mathrm{O}(\mathrm{ZD})(\mathrm{O} /(\mathrm{EO}))(\mathrm{ZD})(\mathrm{EP}) \mathrm{D}$ & $\mathrm{HW}$ & 14 & 45 & 35 & 4.5 & 0.8 \\
\hline Sappi & Ngodwana & $\mathrm{OA}(\mathrm{ZD})(\mathrm{EO}) \mathrm{D}$ & SW & 10 & 72.6 & 18.4 & 6 & 3.4 \\
\hline Votorantim & Celpav & $\mathrm{O}(\mathrm{DZ})(\mathrm{EOP}) \mathrm{D}$ & HW & 11 & 57 & 27 & 3 & 3.8 \\
\hline
\end{tabular}

表 5 排水に与えるオゾン漂白による影響5),12)

\begin{tabular}{|c|c|c|c|c|c|c|c|c|}
\hline \multirow{2}{*}{ 工場名 } & & & パルプ & $\mathrm{AOX}$ & $\mathrm{BOD}$ & $\mathrm{COD}$ & Color & Chlorate \\
\hline & & & \multicolumn{6}{|c|}{ (kg/ODPT) } \\
\hline \multirow{2}{*}{$\begin{array}{l}\text { Union Camp } \\
\text { (Franklin) }\end{array}$} & CEDED & \multirow{2}{*}{$\begin{array}{l}\text { after } \\
\text { lagoon }\end{array}$} & \multirow{2}{*}{ SW } & 6.5 & 16 & 65.5 & 185 & - \\
\hline & $\mathrm{OZ}(\mathrm{EO}) \mathrm{D}$ & & & 0.05 & 4.4 & 11.0 & 3.1 & - \\
\hline \multirow{2}{*}{$\begin{array}{c}\text { Stora } \\
\text { (Billerude) }\end{array}$} & $\mathrm{OAD}(\mathrm{EOP}) \mathrm{DED}$ & \multirow{2}{*}{$\begin{array}{l}\text { before } \\
\text { lagoon }\end{array}$} & \multirow{2}{*}{ SW } & 0.83 & 6.7 & 32.6 & - & 6.8 \\
\hline & $\mathrm{OA}(\mathrm{ZD})(\mathrm{EOP}) \mathrm{DED}$ & & & 0.45 & 6.4 & 29.8 & - & 3.3 \\
\hline
\end{tabular}

る排水処理水質をまとめた。

\section{4. (DZ) もしくは (ZD) 漂白シーケンスの}

\section{漂白薬品コスト}

ECF, TCF 漂白シーケンスにオゾン漂白を取り入 れれば，漂白コストは大幅に減少でき得る。また，才 ゾン発生技術の改良, 特に OZONIA 社製の AT オゾ ン発生機に見られるようにオゾン発生用誘電体, 及び 制御技術の進展も著しくオゾンコストはここ 2 年間で 大幅に下がってきている ${ }^{13)}$ 。

例えば，オゾンコストは， $250 \mathrm{~kg} / \mathrm{hr} の$ OZONIA 社製オゾン発生機を考えた場合, 1.4 US \$（155 円/ $\mathrm{kg}$ ）との報告があるが2)，表6のコスト計算では，パ ルプ生産量 1,000 ton/day 規模の (ZD) シーケンス 用として小さめのサイズのオゾン発生システムを想定 し, 中濃度パルプ処理のために要求される 10 バール までのオゾンガス圧縮コストを含め, 計算上のオゾン コストを 190 円 $/ \mathrm{kg}$ とした。

この漂白薬品コスト試算では, $\mathrm{O}(\mathrm{ZD})(\mathrm{EO}) \mathrm{DED}$ $\mathrm{ECF}$ シーケンスが最小のコストですむことが分かる。 二酸化塩素を用いた従来の ECFシーケンス $\mathrm{OD}$
(EOP) DED と比較しパルプトンあたり約 860 円の節 減が達成でき，年間換算では約 300,000,000 円の漂白 薬品コス卜節減が期待される。

\section{5. オゾン／酸素のパルプエ場での利用}

\section{1 オゾン発生器}

多くの紙パルプ区場では, 酸素脱リグニン及び (EO) 用として酸素がスが漂白用として利用されてい る。オゾンガス発生システムを計画する際に，オゾン 反応器より排出される反応後の酸素ガス利用を各工場 の用途に対して最適なオゾン発生システムを構築する 事が重要となってくる。

現在工業的に実用化されている, 代表的な Once Through 方式とLong Loop 方式を図 2 及び図 3 に 示した。

酸素ガス供給源としては, 酸素がスメーカーで製造 された液体酸素を利用する方法, もしくは各パルプ工 場内オンサイトプラントで発生された酸素がスが利用 される。最近では, 常温吸着分離方式の VSA (Air Liquide Compact VSA）が安価な酸素がス発生力式 として推奨されている。また, オゾン発生機（OZO- 
表 6 （ZD）漂白シーケンス薬品コスト比較

\begin{tabular}{|c|c|c|c|c|c|c|c|c|c|c|}
\hline \multirow{2}{*}{ 漂白シーケンス } & \multirow{2}{*}{$\begin{array}{l}\text { 酸素脱 } \\
\text { リグニ } \\
\text { ン後の } \\
\text { Kappa }\end{array}$} & $\mathrm{Cl}_{2}$ & $\mathrm{ClO}_{2}$ & $\mathrm{NaOH}$ & $\mathrm{O}_{2}$ & $\mathrm{O}_{3}$ & $\mathrm{H}_{2} \mathrm{O}_{2}$ & $\mathrm{H}_{2} \mathrm{SO}_{4}$ & $\mathrm{MgSC}_{4}$ & $\begin{array}{l}\text { 漂白 } \\
\text { コスト }\end{array}$ \\
\hline & & $\begin{array}{c}25 \\
(¥ / \mathrm{kg})\end{array}$ & $\begin{array}{c}130 \\
(¥ / \mathrm{kg})\end{array}$ & $\begin{array}{c}40 \\
(¥ / \mathrm{kg})\end{array}$ & $\begin{array}{c}10 \\
(¥ / \mathrm{kg})\end{array}$ & $\begin{array}{c}190 \\
(¥ / \mathrm{kg})\end{array}$ & $\begin{array}{c}140 \\
(¥ / \mathrm{kg})\end{array}$ & $\begin{array}{c}10 \\
(¥ / \mathrm{kg})\end{array}$ & $\begin{array}{c}60 \\
(¥ / \mathrm{kg})\end{array}$ & (¥/ODPT) \\
\hline (CD) (EOP) DED & 30.8 & 27.7 & 22.3 & 35 & 8 & & 5 & & & 5,771 \\
\hline $\mathrm{D}(\mathrm{EOP}) \mathrm{DED}$ & 30.8 & & 36.7 & 33.3 & 7.8 & & 6.7 & & & 7,119 \\
\hline (DZ) (EOP) DED & 30.8 & & 28.7 & 27.0 & 7.8 & 4 & 6.7 & & & 6,578 \\
\hline $\mathrm{OD}(\mathrm{EOP}) \mathrm{DED}$ & 15 & & 23 & 45 & 25 & - & 3 & - & 2 & 5,580 \\
\hline $\mathrm{O}(\mathrm{ZD})(\mathrm{EO}) \mathrm{DED}$ & 15 & & 13 & 45 & 25 & 4 & - & 10 & 2 & 4,720 \\
\hline
\end{tabular}

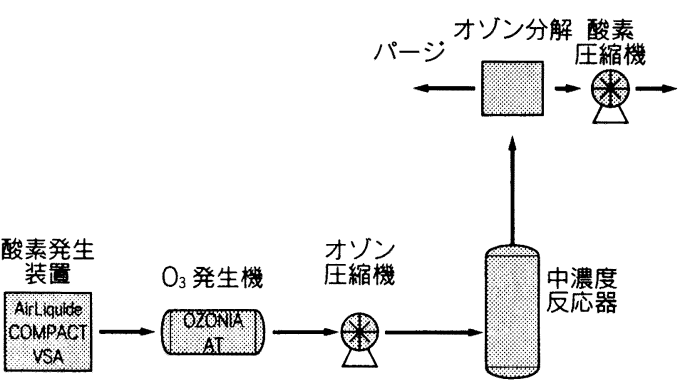

図 2 OnceThrough ブロックダイアグラム

NIA AT）については, 各パルプ工場で採用される パルプ処理濃度が中濃度処理であれば発生オゾン濃度 は処理パルプとの混合効率を高めるために高濃度且つ 圧縮されたオゾンガスが望まれる。高濃度処理では, オゾン濃度はあまりシビアではなく且つ低圧で良い。 各工場の事情に適した酸素ガス発生を含んだ最適の才 ゾン発生システムを AirLiquide グループでは, 各工 場に提案する事が可能である。

オゾン発生システムの構成装置は, 次のような設備 で構成される。

(1)酸素発生装置：液体酸素受入供給設備, 液体酸素 気化供給設備もしくは，オンサイト低温分離酸素 発生装置もしくは，オンサイト常温吸着分離酸素 発生装置 AirLiquide Compact VSA (5 ton/ day $\sim 150$ ton/day)

(2)オゾン発生機：OZONIA AT オゾン発生機（オ ゾン発生濃度 $6 \mathrm{wt} \%$ から $14 \mathrm{wt} \%$ )

(3)オゾン化酸素ガス圧縮機：中濃度, 低濃度処理方 式の場合

(4)排酸素ガス残留オゾン分解器

(5)排酸素ガス精製装䈯：LongLoop の場合

(6)排酸素ガス際厈縮装置：排酸素ガスを酸素脱リグ ニン等の処理に再利用する場合

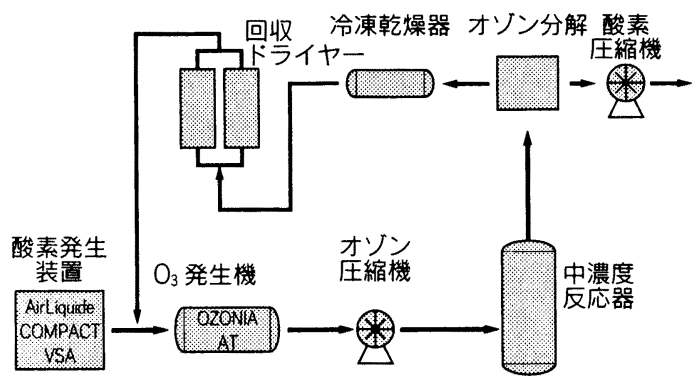

図 3 LongLoop ブロックダイアグラム

\section{2 オゾンガスコスト（図 4)}

オゾン発生コストは, 先にも述べたとおり各工場内 での酸素ガス用途及びパルプ処理方式によって最適な オゾン発生システムを計画する事が必要で, そのコス トはケース毎に変わってくる。ここに 1 例として，パ ルプ生産量 1,000 ton/day の中濃度オゾン漂白を想定 し， 6 ton/day のオゾンを消費する場合についてオン サイトオゾン発生システムによるオゾンコスト試算を 行なった。なおこの試算では，オゾン濃度 $10 \mathrm{wt} \%$, オゾン圧力 10 バール, 電力価格は $5 ¥ / \mathrm{kWh}$, 酸素 ガスは 10 円 $/ \mathrm{kg}$, 冷却水, 計装空気, 一次側ユ一テ イリティ一設備, 基礎建屋の設備費用については, 含 まれていない。

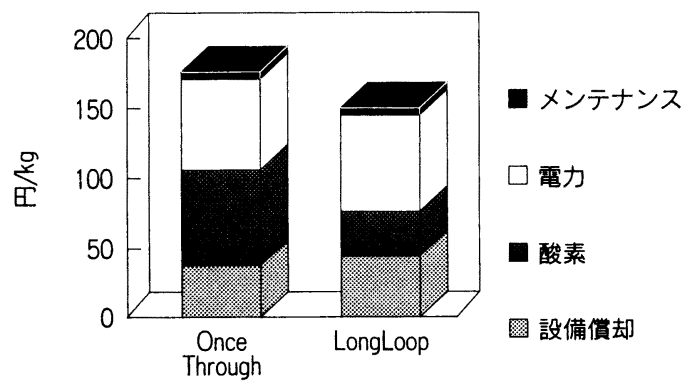

図 4 オゾンコスト試算 
設備償却期間は 10 年間とした。Once Throughの 場合オゾン反応器よりの排酸素ガスは酸素脱リグニン 反応用として使用出来ることとした。またこの方式で は, 38.4 ton/dayの排酸素ガスが他の用途にコスト フリーで利用できる。

オゾン漂白の導入を計画される各工場においては, このオゾン発生システム設備に関して 2 とおりの選択 が出来る。その一つは各工場サイトで各設備に対して の投資を行ない償却, 運転, メンテナンスを行なって いく方法であり, もうひとつの選択肢は, オーバーザ フェンスセールスの形態である。AirLiquide グルー プでは, 各工場に最適なオゾン発生システム設備の投 資を自ら行ない, 且つ運転, メンテナンスを行う，よ つて, 各工場ではオゾンガス配管末端でオゾンガスを 受け入れらることになる。そして，パルプ生産という 中核の業務をわずらわすことなく安定的にまた安心し てオゾンガスを消費することが出来る。

また，長期的なビジネス関係の構築により AirLiquide グループでの開発研究成果, 酸素/オゾンガスの パルプ工程における利用技術に関する knowhow, 例 えばオゾン漂白をべースにした故紙漂白法である REDOXAL プロセス, 過酸化水素利用の漂白法, 酸 素ガスのパルプ工場での利用技術等々を各工場で利用 いただける。

\section{3 紙パルプエ場での酸素ガスの利用}

オゾン漂白反応塔から出てくる酸素りッチな排がス は, 紙パルプ工場内で様々な用途に用いることができ る。

(1)酸素脱リグニン用 : 15〜20 kg/PT

(2)アルカリ抽出用 : $5 \mathrm{~kg} / \mathrm{PT}$

(3)白液の酸化用: $5 \mathrm{~kg} / \mathrm{PT}$

(4)活性污泥処理用

(5)石灰キルンの酸素富化操業用

(6)ポリサルファイドの製造用

\section{4 オゾン/酸素混合ガスの安全性の実験による}

考察 (図 5, 図6)

中濃度パルプでのオゾン漂白に際し, ミキサーでの 反応効率を高めるためにより 10〜15 バールの圧力, $10 \mathrm{wt} \%$ 以上の高いオゾン濃度が求められる。

オゾン化酸素ガスを圧縮した時の急激な分解に対す る, 静的な実験が AirLiquide 及び OZONIA で行わ れている ${ }^{14)}$ 。

オゾン/酸素混合ガスが大気圧下で使用される場合 には，オゾン濃度 $16 \mathrm{wt} \%$ までのオゾン／酸素ガスの 使用に対しては何ら安全上の問題はない。

$16 \mathrm{wt} \%$ のオゾンを含んだオゾン/酸素混合ガスを

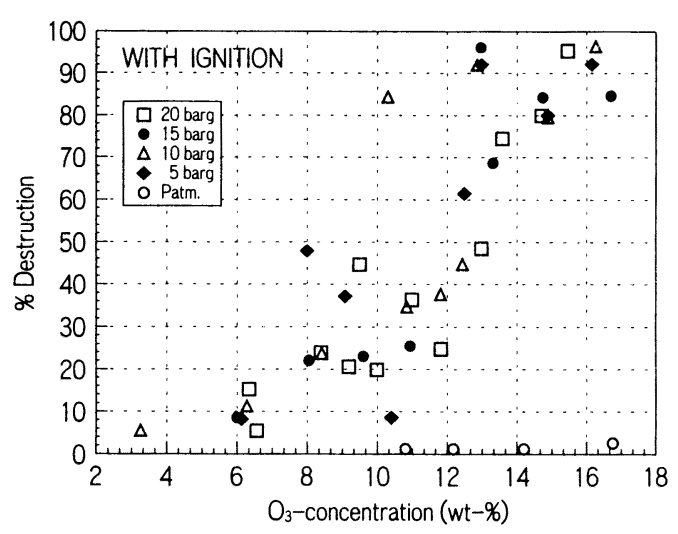

図 5 強制着火を行った際のH:縮オゾンの分解

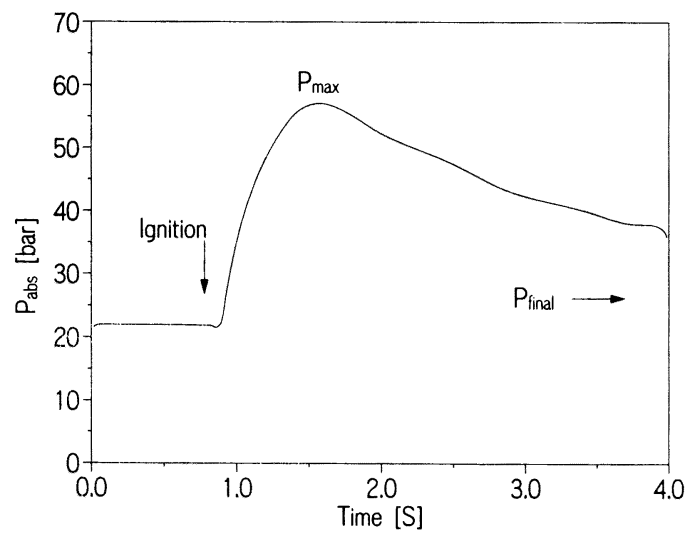

図 6 圧縮オゾン分解時の压力変化

20 パールまで圧縮して $1 \mathrm{hr}$ 放置した場合には，オゾ ンガスの自己分解率は, 初期濃度の $11 \%$ を超えるこ とはなかった。10 分放置後の分解潗は無視できる範 囲であった。オゾン／酸素混合ガスを师絔し，長時間 にわたって放置しても全く多全で，ただ分解による経 済的ロスを生じるのみである。

さらにオゾン/酸素混合ガスを厈縮した後, 強制的 に点火ワイヤでエネルギーを与えた。この場合にのみ, $7 \mathrm{wt} \%$ オゾン濃度以上でオゾンの分解が見られた。こ の時のオゾンの分解状況の観察の中で曝䩴状態はどの ケースも確認できなかった。

圧縮オゾン／酸素混合ガスが点火により分解を生じ た際の最大压力は, オゾン分解率から㖕算された圧力 よりも低い最大圧力が観祭された。これは生じたエネ ルギーが周囲に吸収されたものと考えられる。10 $\mathrm{wt} \%$ オゾン/酸素混合がスが, 初期温度 $25^{\circ} \mathrm{C}$, 初期 圧力が 10 パールの状態で強制的に点火されすべての オゾンが分解を生じな際の最大圷力は, 20 パールで 
ある。

工業的な使用範䎴の中でこの強制的な点火によるオ ゾンの分解は，早患のシナリオを描いたものである。

\section{6. 結 論}

オゾン漂けは, 多くのパルプエ場で様々なパルプ, ソフトゥッド, ハードウッド, 故紙の漂白方法として 使用されている。TCF 漂白シーケンスのみならず $\mathrm{ECF}$ シーケンス, さらには, TEF シーケンスに使用 されている。

経済的見地よりも，オゾンの利用は二酸化塩素の利 用よりも20 30\%のコスト減となり得る。また，才 一バーザフェンスセールスを利用すれば，最適なオゾ ン発生システムが初期投資, マンパワーをさくことな く利用できる。

二酸化壏素とオゾンを組み合わせた $(\mathrm{DZ}) \mathrm{ECF} シ$ ーケンスは, 二酸化塩素単独での ECF シーケンスよ りも経济的であり，またパルププロセスの大きな設備 投資を伴わずに環境問題の解決がすぐさま可能となる。 そして, 将来の環境規制, 市場要求に求められるであ ろう TEF への展開が可能となる。

AirLiquide グループは, ECF, TCF, TEF シー ケンスに利用される酸素, オゾン, 過酸化水素及び設 備, 利用技術について最適なサービスを提供出来る唯 一の会社であると信じている。

\section{参考文献}

1) Homer, G. Muguet, M. : “Oxygen, Ozon and Chlorine Dioxyde”, 1996, CPPA, Annual Meeting, Montreal, Canada.

2) Homer, G. and Govers, T.: "Ozone Based ECF and TCF bleaching: Experience, Laboratory Data, and Cost Considerations", 1994 TAPPI Pulping Conference, San Diego, pp. 1051-1061.

Govers, T., Homer, G. and Scheeff, D. : "The cost of ozone-based ECF and TCF bleaching”, 1995 Air Liquide/Ozonia Ozone Symposium, Helsingor, section 3.

3) Jory, N. : "From Oxygen to Ozone-A View From South Africa", 1995 Air Liquide/ Ozonia Ozone Symposium, Helsingor, section 1

4) Winberg, K. : "Experiences with Ozone in TCF and ECF Bleaching of Kraft Pulp", 1995 Air Liquide/Ozonia Ozone Symposium,
Helsingor, section 13

5) Helander R., Nilsson, B., Bohman G. : "Development and Progress in Ozone Bleaching at the Skogal Mill”, 1994 International Pulp Bleaching Conference, Vancouver, pp 289-291.

6) Dahllof, H. : "Current Projects with Ozone Bleaching”, 1995 Air Liquide/Ozonia Ozone Symposium, Helsingor, section 6 .

7) Soderling, F. : 1995 Non-Chlorine Bleaching Conference, The Panel Discussion on Pulp Quality and Economics of ECF vs TCF Bleaching-session 7.

8) Lachenal D. : "Selectivity in Ozone Bleaching”, 1995 Air Liquide/Ozonia Ozone Symposium, Helsingor, section 5

9) Xu., J., Cogo, E., Briois, L., Duprat, S., Molinier, J., Coste, C., Kalck, P. : Towards a Selective Ozone Bleaching Stage by Addition of Organic Oxygenates", Pulp \& Paper, Canada, September 1995, pp.49-53.

10) Dilner, B. and Tibbling. : "Use of Ozone at Medium Consistency for Fully Bleached Pulp Process Concept and Effuluent Characteristics”, 1991 International Pulp Bleaching Conference, Stockholm, pp.59-73.

11) Pryke, D., Bourree, G., Winter, P., and Mickowski, C. : "The Impact of Chlorine Dioxyde Delignification on Pulp Manufacuring and Effkuent Characterstics at Grande Prairie, Alberta”, 1993 International NonChlorine Bleaching Conference, Hilton Head, Paper 11.

12) Nutt, W., 1995 Non Chlorine Bleaching Conference, The Panel iscussion on Environmental Issues and Technical Trends in Bleaching-session 1.

13) Wiegart, N., "Progress in Ozone Generation Technology”, 1995 Air Liquide/Ozonia Ozone Symposium, Helsingor, section 2.

14) Armengaud, B., Schmid, E., Thonnelier J., Nicolas, J., Lang, H., "Concentrated Oxygen-Ozone Mixtures Stability at High Pressure" 